\title{
KANDUNGAN LOGAM BERAT DALAM UDARA AMBIEN PADA BEBERAPA KOTA DI INDONESIA
}

\section{HEAVY METAL CONCENTRATIONS OF AIR AMBIENT IN SEVERAL CITIES IN INDONESIA}

\author{
Rita Mukhtar ${ }^{1}$, Hari Wahyudi ${ }^{1}$, Esrom Hamonangan ${ }^{1}$, Susy Lahtiani ${ }^{1}$, Muhayatun Santoso², \\ Diah Dwiana Lestiani², dan Syukria Kurniawati²
}

(Diterima tanggal 15-04-2013; Disetujui tanggal 01-08-2013)

\begin{abstract}
ABSTRAK
Pencemaran udara terutama di kota-kota besar (ibukota provinsi) telah menjadi salah satu masalah yang serius. Kontribusi pencemar terbesar berasal dari emisi gas buang kendaraan bermotor, industri, pembangkit listrik, dan kegiatan rumah tangga. Bahan pencemar udara yang ditimbulkan dapat berupa gas maupun partikulat debu. Di Indonesia, saat ini belum tersedia data series khususnya data logam berat di udara ambien. PUSARPEDAL sesuai dengan tugas pokok dan fungsinya melakukan pemantauan bekerjasama dengan Badan Tenaga Nuklir Nasional (BATAN) dalam rangka pemanfaatan iptek nuklir untuk perlindungan dan pengelolaan lingkungan hidup. Pengambilan contoh uji menggunakan alat Gent Staked Filter Unit sampler seminggu sekali pada tahun 2012 pada 10 kota di Indonesia. Analisis logam berat dilakukan dengan menggunakan Energy Dispersive X-Ray Fluorescence (ED-XRF). Kisaran kadar unsur (ng/m3) Na, Mg, Al, Si, S, K, Ca, Cr, Mn, Fe, Co, Ni, Cu, Zn, dan Pb, secara berurut adalah; $1,90-667 ; 1,33-786 ; 0,13-1020 ; 0,2-744 ; 2,54-1397 ; 3,7-640 ; 0,48-381 ; 1,3-7,2 ; 0,02$ $-22,5 ; 1,94-1561 ; 0,018-18,52 ; 0,26-13 ; 0,05-18,79 ; 2,9-913 ; 0,2-2664,2$.
\end{abstract}

Kata kunci: udara ambien,logam berat, Gent Staked Filter Unit sampler, X-Ray Fluorescence

\begin{abstract}
Air pollution in big cities (province capital) has become serious problem. The major contributions are from emission gas from motor vehicles, industrial activities, electric power generator and domestic activities. Air pollution parameters are in gas and particulate form, which at present the data series especially for heavy metals in ambient are not available. PUSARPEDAL with the main task and function to do the monitoring of environmental quality has a research cooperation with National Nuclear Energy Agency of Indonesia for implementation of nuclear technique for environmental management and protection, to obtain the data series of heavy metal in air ambient. Samplings were carried out once a week using Gent Staked Filter Unit sampler at 2012 in 10 cities in Indonesia. Heavy metal analysis was done using Energy Dispersive X-Ray Fluorescence (ED-XRF). The range of elemental concentrations (ng/m3) Na, Mg, Al, Si, S, K, Ca, Cr, Mn, Fe, Co, Ni, Cu, Zn, and Pb, in PM2.5 was; 1,90 - 667; $1,33-786 ; 0,13-1020 ; 0,2-744 ; 2,54-1397 ; 3,7-640 ; 0,48-381 ; 1,3-7,2 ; 0,02-22,5 ; 1,94-1561 ; 0,018$ $-18,52 ; 0,26-13 ; 0,05-18,79 ; 2,9-913 ; 0,2-2664,2$.
\end{abstract}

Keywords: air pollution, heavy metals, Gent Staked Filter Unit sampler, X-Ray Fluorescence

\section{PENDAHULUAN}

Logam berat merupakan salah satu bahan pencemar udara ambien yang ikut bersama partikulat udara. Keberadaan logam berat di udara ambien dapat disebabkan karena aktifitas manusia maupun faktor alam. Baku mutu untuk logam berat di udara ambien belum banyak diatur di dalam Lampiran Peraturan Perundang-undangan Indonesia

\footnotetext{
PUSARPEDAL - Kementerian Lingkungan Hidup

2 PTNBR - Pusat Teknologi Nuklir Bahan dan Radiometri- Badan Tenaga Nuklir Nasional
} 
PP No. 41 Tahun 1999 tentang Pengendalian Pencemaran Udara, kecuali untuk logam berat timbal $(\mathrm{Pb})$ yang diukur dengan metode gravimetri analisis ekstraksi pengabuan menggunakan alat sampling High Volume Air Sampler (HVAS) dan analisis menggunakan Atomic Absorption Spectrofotometry (AAS), yaitu $2 \mu \mathrm{g} / \mathrm{Nm}^{3}[1,2]$.

Total Suspended Partikulate (TSP) merupakan partikel atau aerosol $<100$ mikrometer partikel kasar tersaring dalam sistem pernafasan atas, $\mathrm{PM}_{10}$ partikel halus atau aerosol berdiameter hingga 10 mikrometer dapat masuk kedalam sistem pernafasan. $\mathrm{PM}_{2.5}$ partikel sangat halus dibawah 2,5 mikrometer yang dapat masuk ke dalam paru-paru, sangat berbahaya karena ukurannya sangat halus. Partikel sangat halus dapat mengandung logam. Logam berat dalam bentuk partikel dapat mempengaruhi kesehatan manusia jika masuk kedalam pernapasan kemudian menembus ke bagian dalam paru-paru manusia, dapat menimbulkan berbagai penyakit seperti ISPA, gejala anemia, hambatan dalam pertumbuhan, sistem kekebalan tubuh yang lemah, gejala autis, kanker paru-paru, bahkan kematian dini.

Pusat Sarana Pengendalian Dampak Lingkungan (PUSARPEDAL) merupakan salah satu unit kerja yang ada dibawah Kementerian Lingkungan Hidup (KLH) yang telah menjalin kerjasama dengan BATAN khususnya kelompok Teknik Analisis Radiometri dalam penelitian kajian dan monitoring pencemaran udara sejak tahun
2008. Berbagai kegiatan telah dilakukan antara lain kajian pencemaran timbal di udara ambien di Tangerang dan sekitarnya.

Pada makalah ini dilakukan penentuan kandungan beberapa unsur logam berat didalam $\mathrm{PM}_{2.5}$. Hasil yang diperoleh diharapkan dapat memberikan kontribusi, mendukung dan mendorong pemerintah untuk membuat kebijakan yang tepat dan terarah dalam upaya meningkatkan kualitas udara di Indonesia agar gangguan kesehatan dan kerugian ekonomi yang lebih besar dapat dihindari. Dan bagi pengambil kebijakan, data ini dapat digunakan sebagai data dasar dalam kajian baku mutu logam berat di udara ambien di Indonesia.

\section{METODOLOGI}

\section{Pengambilan Contoh Uji (Sampling)}

Pengambilan contoh uji dilakukan dengan menggunakan alat Gent stacked filter unit sampler yang berlangsung selama 24 jam dengan laju alir berada pada rentang 15$18 \mathrm{~L} / \mathrm{min}$. Alat Gent stacked filter unit sampler terdiri dari dua filter, yaitu filter jenis Nuclepore polikarbonat yang ukuran pori filter $0,4 \mu \mathrm{m}$ digunakan untuk penentuan logam berat dalam $\mathrm{PM}_{2,5}$ dan filter berukuran pori $8 \mu \mathrm{m}$ yang akan digunakan untuk penentuan logam berat dalam $\mathrm{PM}_{2,5-10}[3,4]$. Pengambilan contoh uji di beberapa kota dilakukan pada tahun 2012 periode waktu yang berbedabeda, peta lokasi sampling partikulat udara di beberapa kota disajikan pada Gambar 1 . 


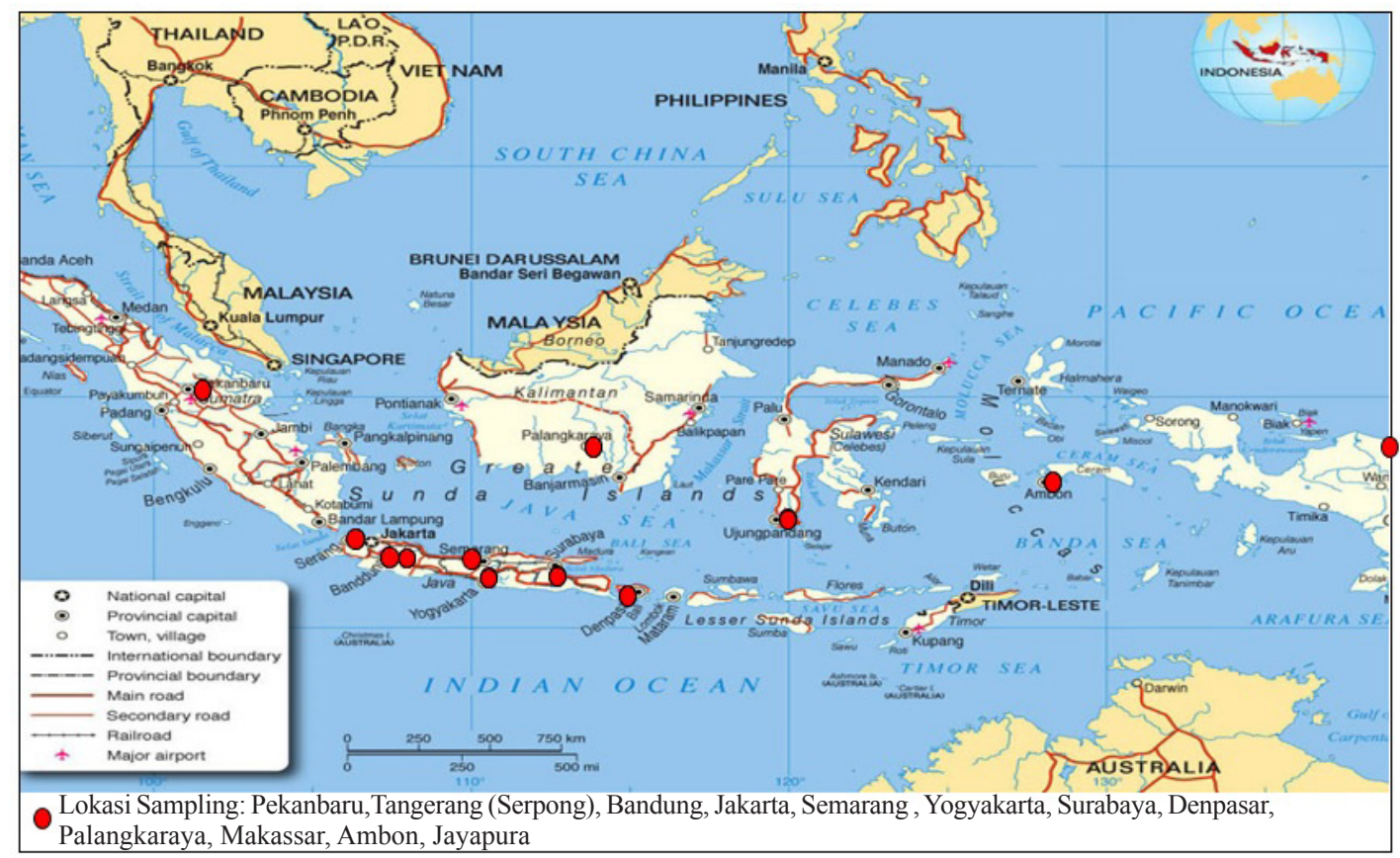

Gambar 1. Peta Lokasi Sampling Logam Berat pada Partikulat Udara pada Beberapa Kota di Indonesia

\section{Analisis Contoh Uji}

Analisis logam berat dilakukan dengan menggunakan EDXRF Epsilon 5 dengan metode Analisis spectrum X-ray yang merupakan teknik analisis nuklir X-Ray Fluorescence (XRF), unsur yang dianalisis adalah unsur yang berada didalam $\mathrm{PM}_{2.5}$. Analisis dilakukan di Pusat Teknologi Nuklir Bahan dan Radiometri-Batan Bandung.

Pemilihan metode didasarkan pada teknik analisis unsur yang sangat selektif dengan kepekaan tinggi, simultan dan memiliki batas deteksi mencapai orde nanogram. Metode ini sangat sesuai digunakan untuk analisis jumlah sampel yang relatif banyak terkadang mencapai ratusan buah filter dan berat sampel per filter yang hanya sedikit $100-600 \mu \mathrm{g}$. Metode yang digunakan untuk analisis unsur telah divalidasi sebagai kontrol kualitas data yang didapatkan. Validasi metode dilakukan menggunakan SRM (Standard Reference Material) Air Particulate on Filter Media. [5,6,7].

\section{HASIL DAN PEMBAHASAN}

Kisaran hasil analisis 15 unsur ; $\mathrm{Na}, \mathrm{Mg}, \mathrm{Al}$, $\mathrm{Si}, \mathrm{S}, \mathrm{K}, \mathrm{Ca}, \mathrm{Cr}, \mathrm{Mn}, \mathrm{Fe}, \mathrm{Co}, \mathrm{Ni}, \mathrm{Cu}, \mathrm{Zn}, \mathrm{Pb}$. yang terdapat pada $\mathrm{PM}_{2.5}$ di udara ambien di 10 Kota yaitu Yogyakarta, Semarang, Surabaya, Palangkaraya, Pekanbaru, Bandung, Jakarta, Tangerang, Bali, dan Makassar disajikan pada grafik $1 \mathrm{~s} / \mathrm{d} 15$. 
Keterangan Pembacaan Grafik:
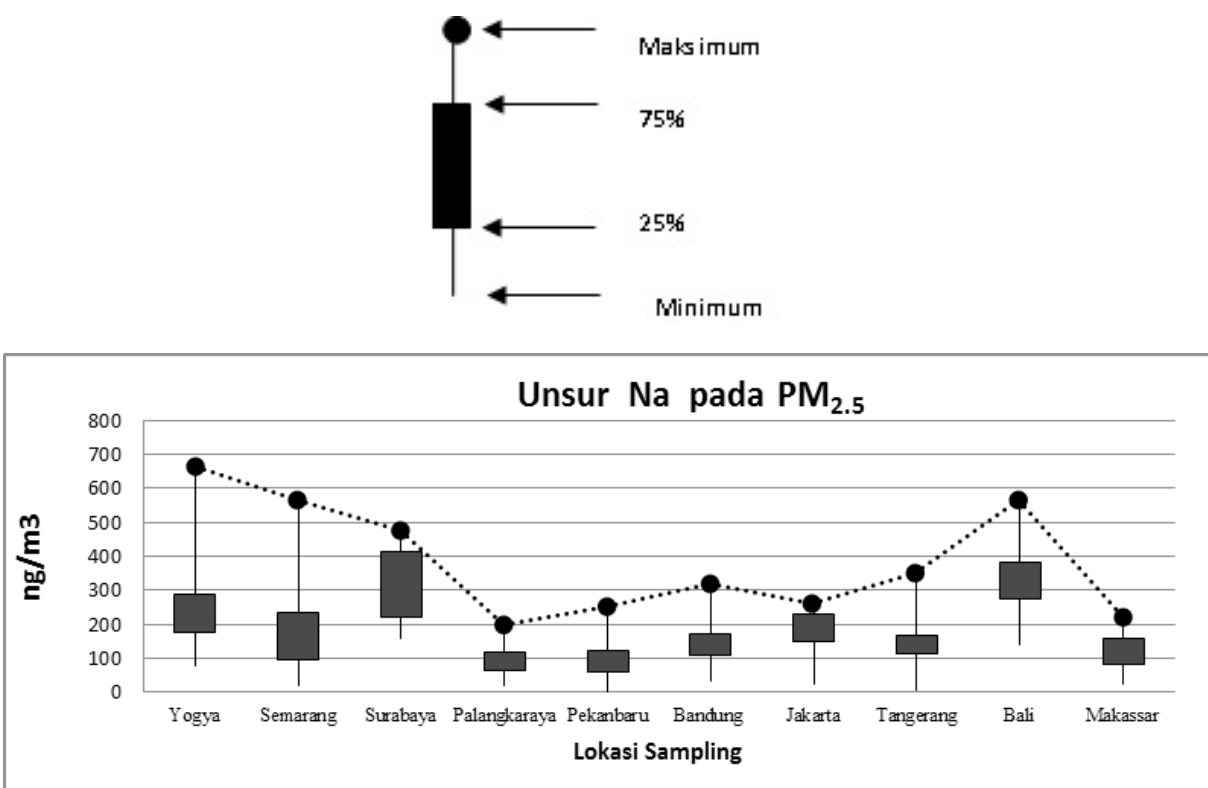

Grafik 1. Kisaran Konsentrasi Na dalam $\mathrm{PM}_{2.5}$ Pada Beberapa Kota di Indonesia

Kisaran natrium $(\mathrm{Na})$ di beberapa lokasi bersamaan dengan $\mathrm{Cl}$. $[8,9,10]$.

sampling berkisar antara $1.9-667 \mathrm{ng} / \mathrm{m}^{3}$, disajikan pada Grafik 1. Keberadaan $\mathrm{Na}$ diudara ambien dapat berasal dari seasalt (garam laut). $\mathrm{NaCl}$ merupakan $90 \%$ berat kering air laut. Penguapan Na biasanya

Kisaran magnesium $(\mathrm{Mg})$ di lokasi yang dipantau adalah $1,33-786 \mathrm{ng} / \mathrm{m}^{3}$, disajikan pada Grafik 2. Sumber Mg dapat berasal dari air laut dan dari tanah $[8,9,10]$.

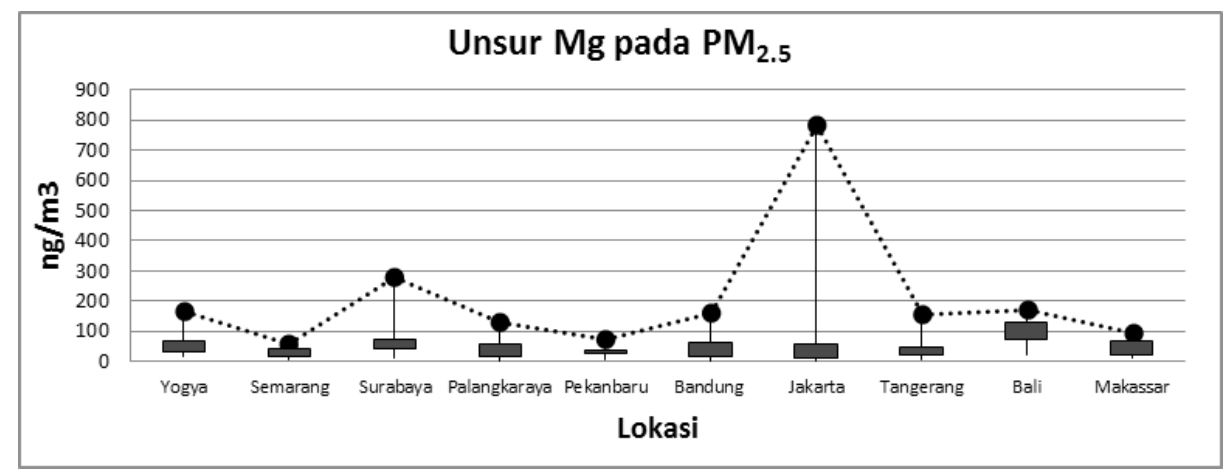

Grafik 2. Kisaran Konsentrasi Mg dalam $\mathrm{PM}_{2.5}$ Pada Beberapa Kota di Indonesia

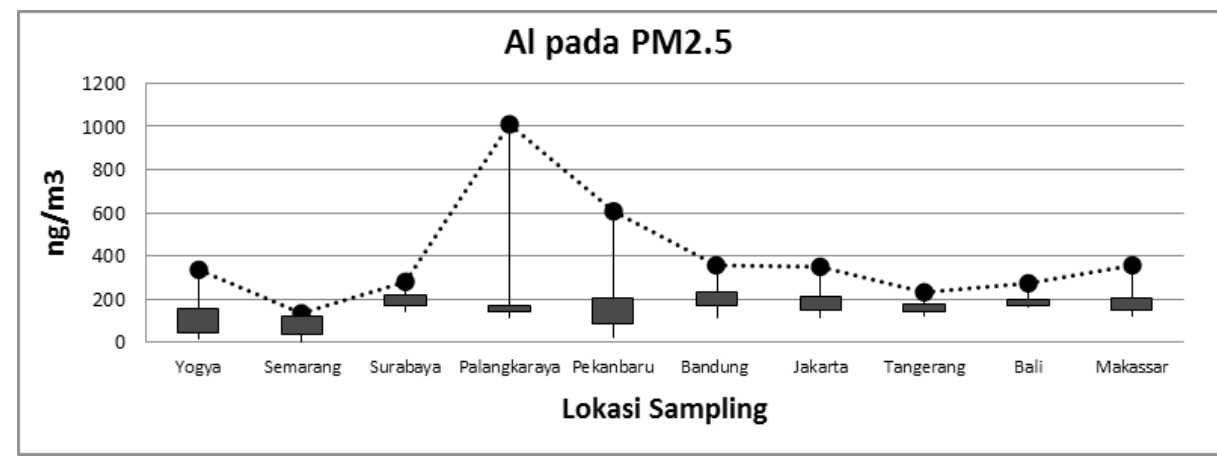

Grafik 3. Kisaran Konsentrasi Al dalam $\mathrm{PM}_{2.5}$ Pada Beberapa Kota di Indonesia 


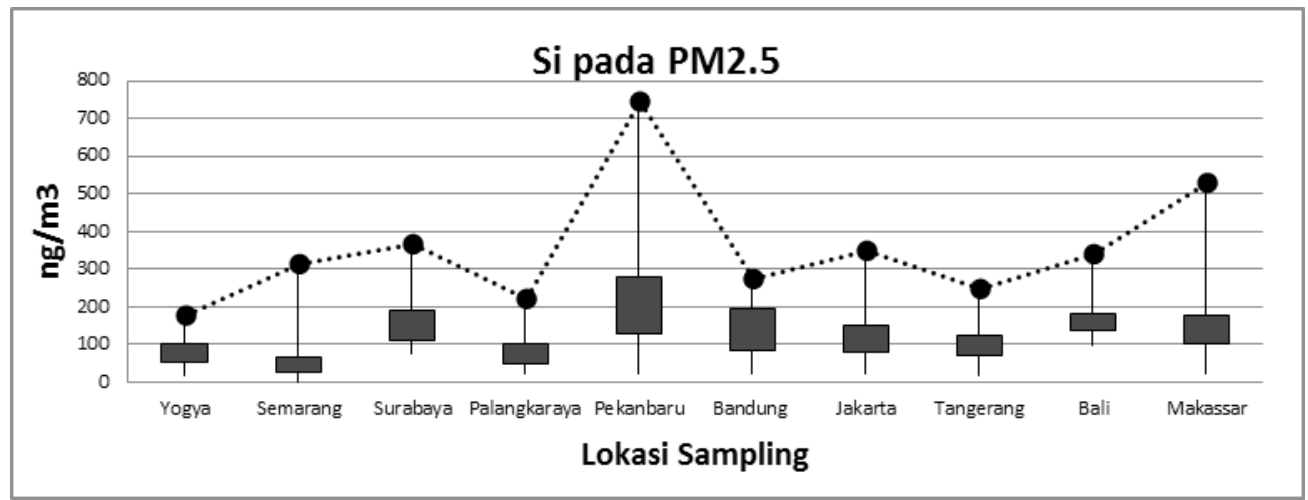

Grafik 4. Kisaran Konsentrasi Si dalam $\mathrm{PM}_{2.5}$ Pada Beberapa Kota di Indonesia

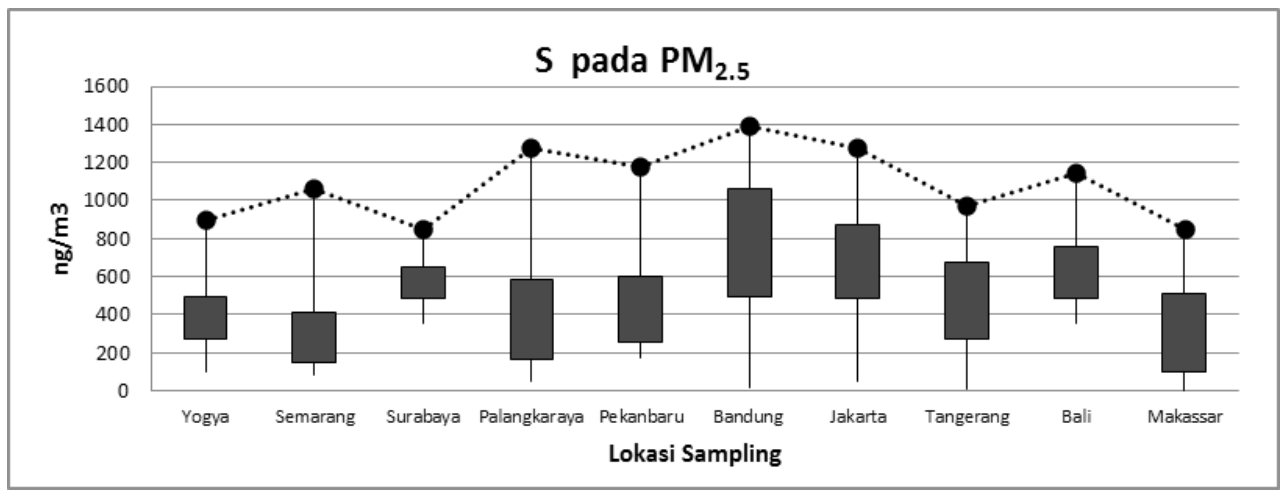

Grafik 5. Kisaran Konsentrasi S dalam $\mathrm{PM}_{2.5}$ Pada Beberapa Kota di Indonesia

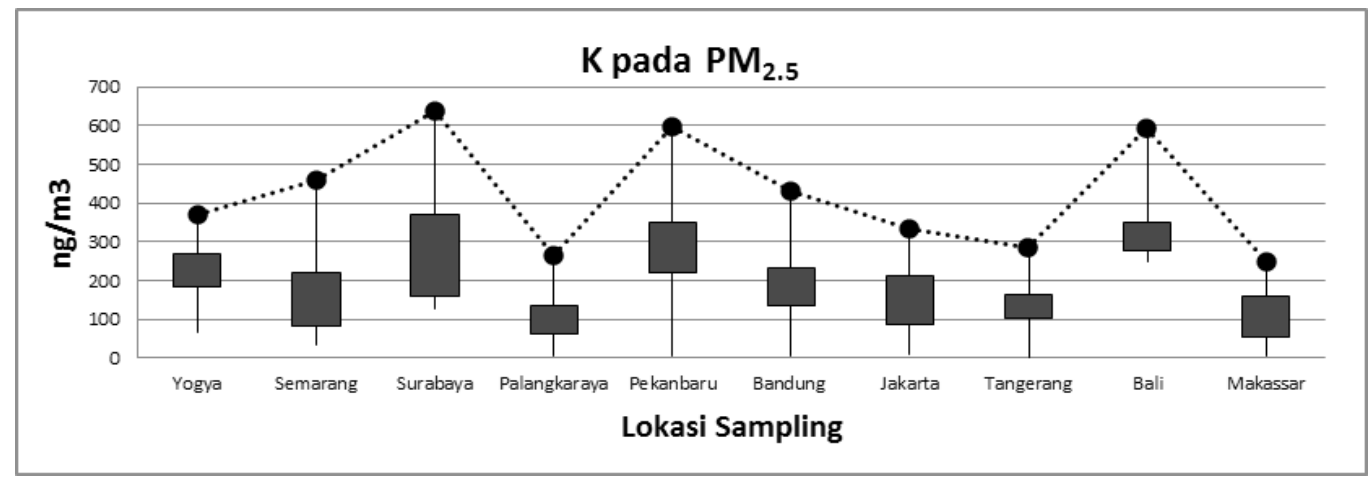

Grafik 6. Kisaran Konsentrasi K dalam $\mathrm{PM}_{2.5}$ Pada Beberapa Kota di Indonesia

Aluminium (Al) bisa berasal dari tanah, seperti pada pembukaan lahan baru[8,9,10]. Kisaran Al di daerah yang dipantau adalah $0,13-1020$ $\mathrm{ng} / \mathrm{m}^{3}$, disajikan pada Grafik 3.

Silika (Si) dapat berasal dari tanah $[8,9,10]$, kisaran Si didaerah yang dipantau adalah $0,2-$ $744 \mathrm{ng} / \mathrm{m}^{3}$, Grafik 4. Menyajikan nilai kisaran Si di beberapa kota di Indonesia.
Sulfur (S) dapat berasal dari air laut, pembakaran batu bara, secondary sulphat, emisi dari industri, kendaraan bermotor $[8,9,10]$. Kisaran $\mathrm{S}$ di daerah yang dipantau adalah $2,54-1397 \mathrm{ng} / \mathrm{m}^{3}$.

Sumber kalium (K) di udara dapat berasal dari pembakaran biomassa (biomass burning), asap (smog), kisaran K disajikan pada Grafik 6. Pembakaran biomassa dapat menyumbang 


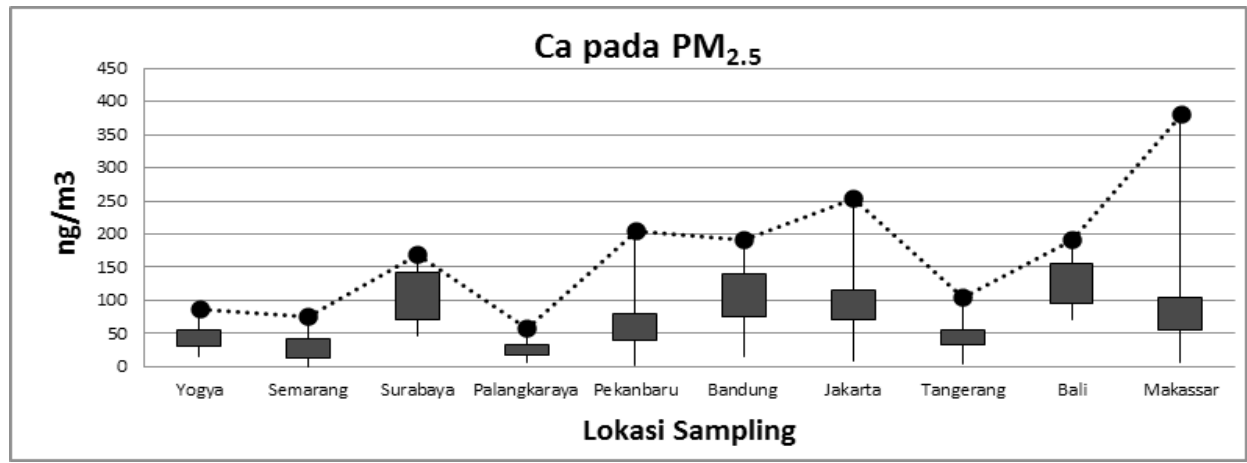

Grafik 7. Kisaran Konsentrasi Ca dalam $\mathrm{PM}_{2.5}$ Pada Beberapa Kota di Indonesia

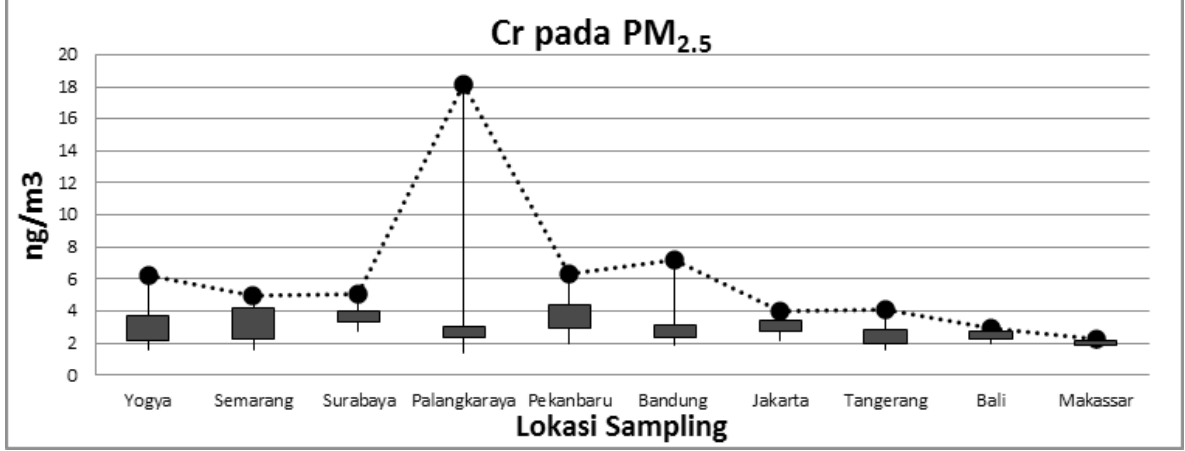

Grafik 8. Kisaran Konsentrasi Cr dalam $\mathrm{PM}_{2.5}$ Pada Beberapa Kota di Indonesia

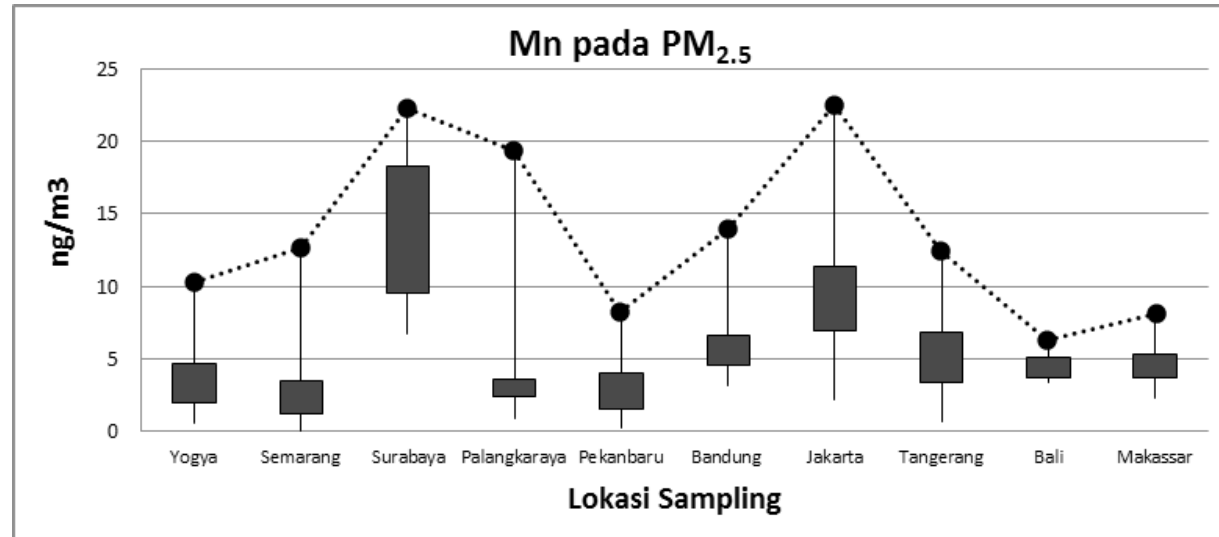

Grafik 9. Kisaran Konsentrasi Mn dalam $\mathrm{PM}_{2.5}$ Pada Beberapa Kota di Indonesia

sumber pencemar $\mathrm{K}$ di udara ambien [5]. Kisaran K di daerah yang dipantau adalah $3,7-640 \mathrm{ng} / \mathrm{m}^{3}$.

Kalsium (Ca) bersumber dari tanah atau soil $[8,9,10]$. Kisaran Ca di beberapa kota yang dipantau adalah $0,48-381 \mathrm{ng} / \mathrm{m}^{3}$.

Kisaran kromium (Cr) di beberapa kota yang dipantau yaitu $1,3-7,2 \mathrm{ng} / \mathrm{m}^{3}$, disajikan pada Grafik 8. Cr dapat berasal dari kegiatan industri $[8,9,10]$.

Kisaran Mangan (Mn) di beberapa kota yang dipantau yaitu $0,02-22,5 \mathrm{ng} / \mathrm{m}^{3}$, disajikan pada Grafik 9. Sumber Mn dapat berasal dari $\operatorname{tanah}[8,9,10]$.

Kisaran besi $(\mathrm{Fe})$ di lokasi yang dipantau adalah 1,94 - $1561 \mathrm{ng} / \mathrm{m}^{3}$, disajikan pada 


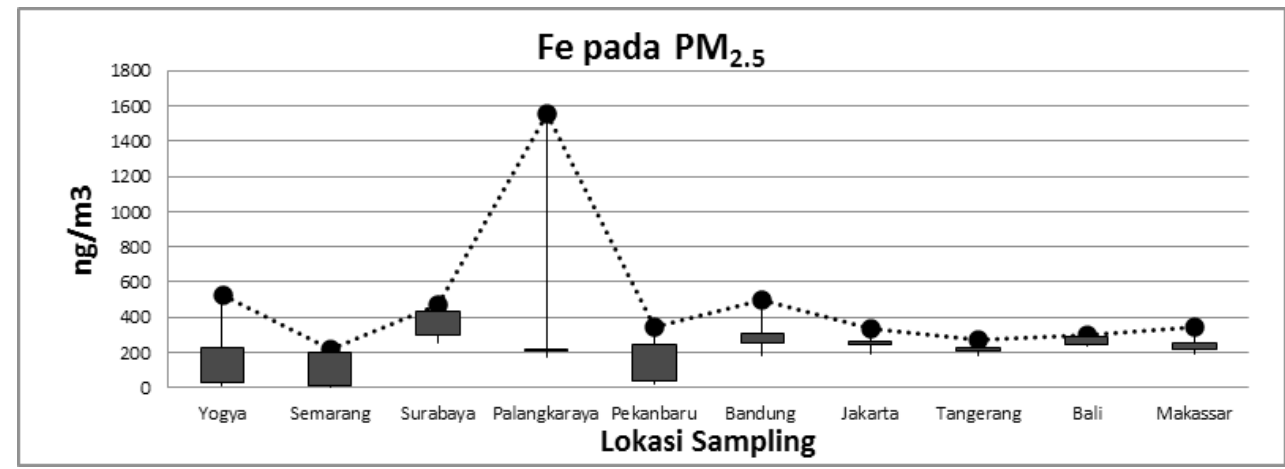

Grafik 10. Kisaran Konsentrasi Fe dalam $\mathrm{PM}_{2.5}$ Pada Beberapa Kota di Indonesia

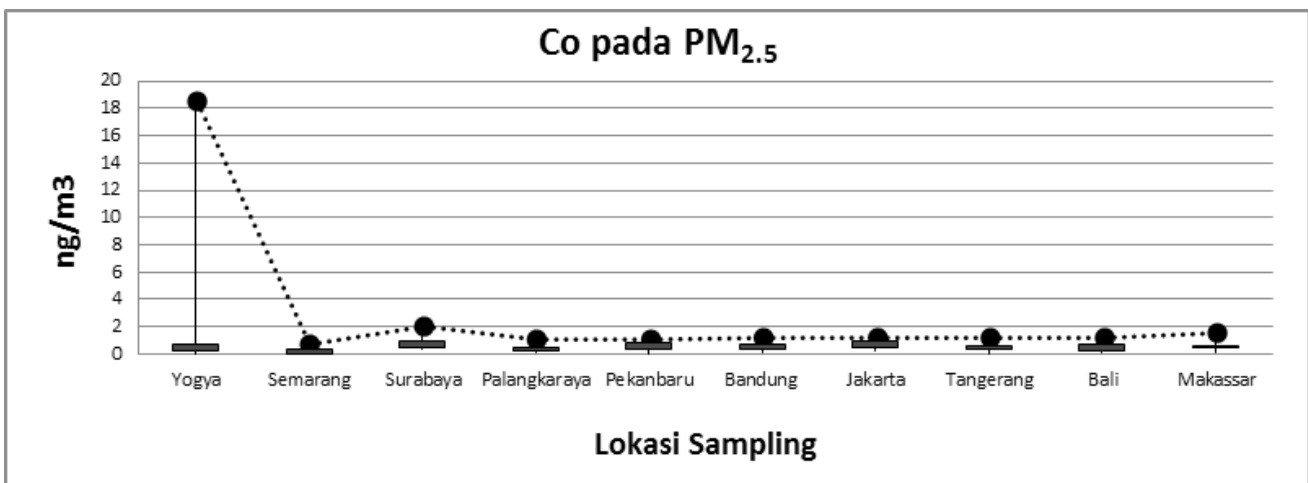

Grafik 11. Kisaran Konsentrasi Co dalam $\mathrm{PM}_{2.5}$ Pada Beberapa Kota di Indonesia

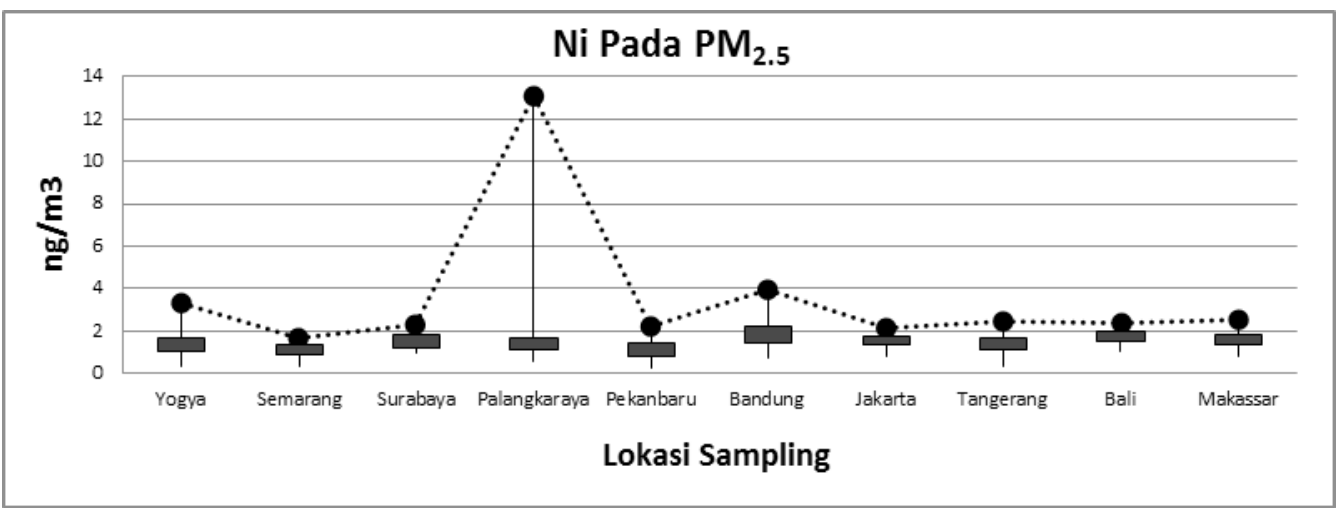

Grafik 12. Kisaran Konsentrasi Ni dalam $\mathrm{PM}_{2.5}$ Pada Beberapa Kota di Indonesia

Grafik 10. Keberadaan Fe dapat berasal dari tanah, dan kegiatan industri[ $[8,9,10]$.

Kisaran kobalt (Co) di lokasi yang dipantau adalah $0,018-18,52 \mathrm{ng} / \mathrm{m}^{3}$. Keberadaan Co dapat berasal dari kegiatan industri $[8,9,10]$.

Kisaran nikel (Ni) pada lokasi sampling yang dipantau adalah $0,26-13 \mathrm{ng} / \mathrm{m}^{3}$, disajikan pada Grafik12. Ni dapat berasal dari minyak atau diesel[$[8,9,10]$.
Kisaran copper $(\mathrm{Cu})$ di lokasi yang dipantau adalah $0,05-18,79 \mathrm{ng} / \mathrm{m}^{3}$, disajikan pada Grafik13. Sumber $\mathrm{Cu}$ dapat berasal dari industri $[8,9,10]$.

Kisaran seng (Zn) di lokasi yang dipantau adalah $2,9-913 \mathrm{ng} / \mathrm{m}^{3}$, disajikan pada Grafik 14. 25\%-75\% data Zn di Surabaya cukup tinggi jika dibandingkan dengan lokasi lainnya. Zn dapat berasal dari kegiatan industri, seperti industri peleburan logam (elektroplating) $[8,9,10]$. 


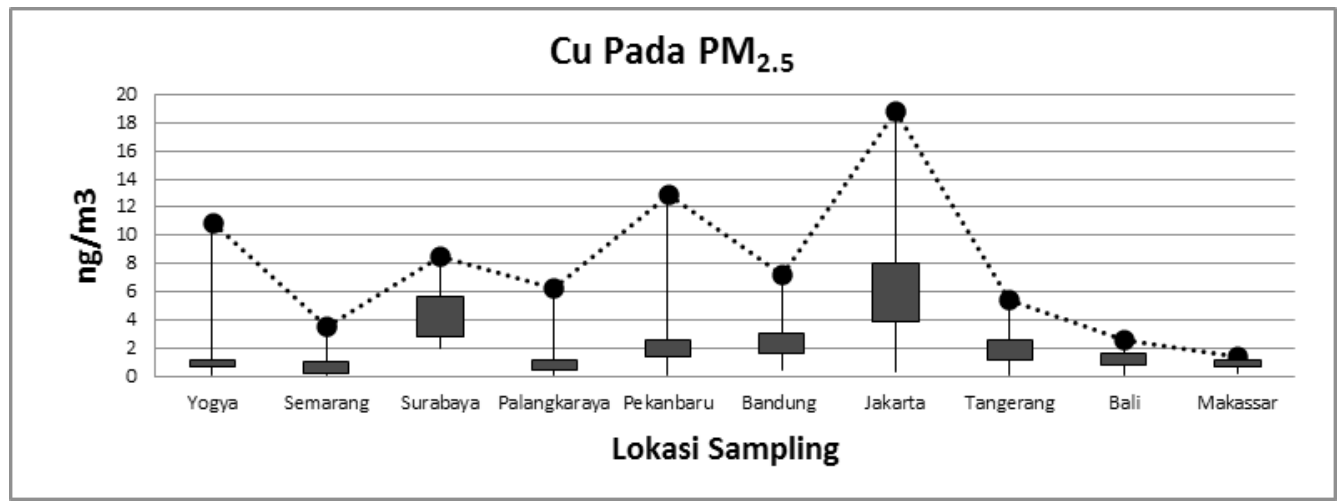

Grafik 13. Kisaran Konsentrasi Cu dalam $\mathrm{PM}_{2.5}$ Pada Beberapa Kota di Indonesia

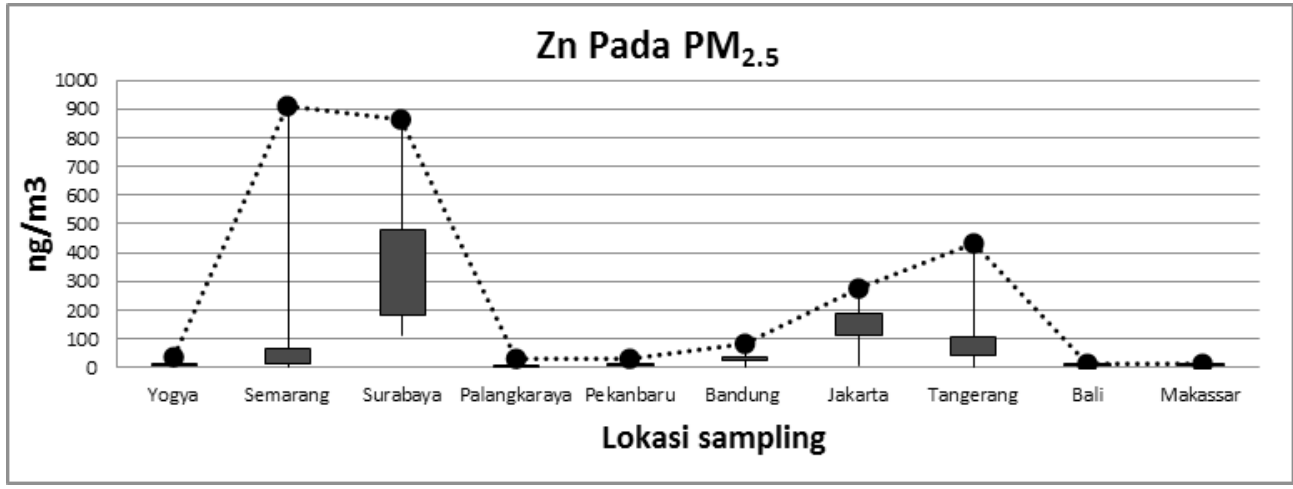

Grafik 14. Kisaran Konsentrasi Zn dalam $\mathrm{PM}_{2.5}$ Pada Beberapa Kota di Indonesia

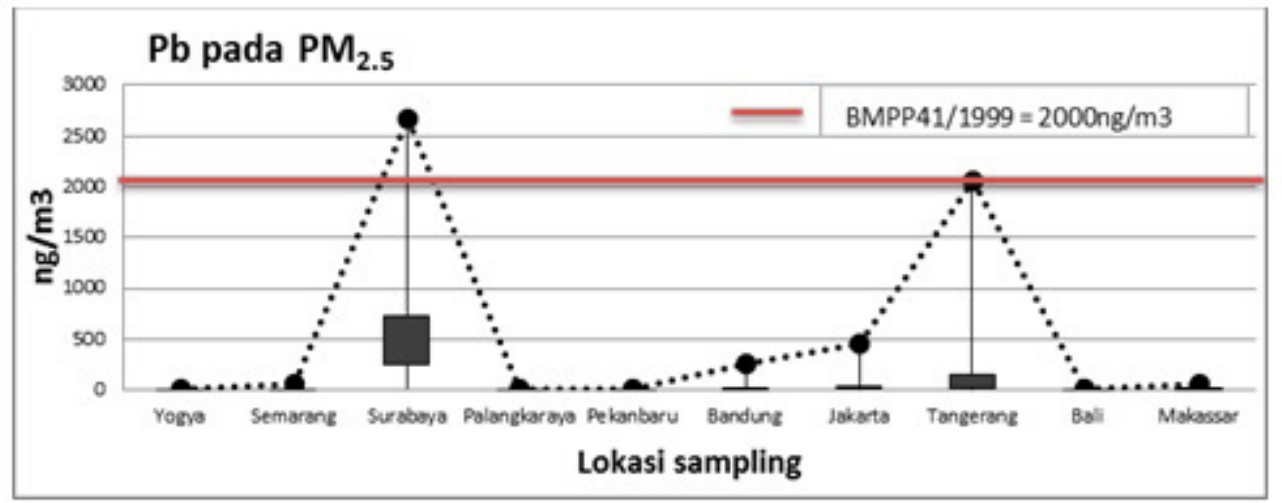

Grafik 15. Kisaran Konsentrasi $\mathrm{Pb}$ dalam $\mathrm{PM}_{2.5}$ Pada Beberapa Kota di Indonesia

Timbal $(\mathrm{Pb})$ merupakan unsur yang telah diatur dalam Peraturan Pemerintah No. 41/1999 tentang Pengendalian dan Pencemaran Udara, dengan baku mutu $\mathrm{Pb}$ dalam Total Suspended Particulate (TSP) adalah $2 \mu \mathrm{g} / \mathrm{Nm}^{3}$ atau $2000 \mathrm{ng} / \mathrm{Nm}^{3}$. Pb yang diukur pada makalah ini adalah $\mathrm{Pb}$ yang menggunakan alat Gent sampler, Pb dalam ukurannya kecil dari 2.5 $\mu \mathrm{m}$ atau $\left(\mathrm{PM}_{2.5}\right)$. Konsentrasi $\mathrm{Pb}$ tertinggi terdapat di Surabaya yaitu $2664 \mathrm{ng} / \mathrm{m}^{3}$, kemudian Serpong-Tangerang yaitu 2045 ng/ $\mathrm{m}^{3}$, dan telah melebihi baku mutu, disajikan pada Grafik 15. Pb dapat dihasilkan dari emisi industri dan kendaraan bermotor.

Kisaran konsentrasi $\mathrm{Pb}$ di udara ambien di beberapa kota di Indonesia yaitu 0,2 - 2664,2 
Tabel 1. Kisaran Konsentrasi Pb di Beberapa Kota di Indonesia

\begin{tabular}{|c|c|c|c|c|c|}
\hline \multirow{2}{*}{ Lokasi } & \multicolumn{5}{|c|}{ Range $\mathrm{Pb} \mathrm{ng} / \mathrm{m}^{3}$} \\
\hline & & Min & & Max & \\
\hline Yogya & ( & 0.61 & - & 12.23 & ) \\
\hline Semarang & ( & 2.24 & - & 61.95 & ) \\
\hline Surabaya & ( & 10.43 & - & 2664.2 & ) \\
\hline Palangkaraya & ( & 0.18 & - & 5.47 & ) \\
\hline Pekanbaru & ( & 0.20 & - & 14.11 & ) \\
\hline Bandung & ( & 1.86 & - & 254.4 & ) \\
\hline Jakarta & ( & 2.71 & - & 456.93 & ) \\
\hline Tangerang & ( & 0.97 & - & 2045.0 & ) \\
\hline Bali & ( & 1.19 & - & 8.24 & ) \\
\hline Makassar & ( & 0.67 & - & 46.97 & ) \\
\hline
\end{tabular}

Tabel 2. Kisaran Konsentrasi Na, Al, S, K, dan Fe di beberapa Kota di Indonesia

\begin{tabular}{|c|c|c|c|c|c|c|c|c|c|c|c|c|c|c|c|c|c|c|c|c|c|c|c|c|c|}
\hline Lokasi & \multicolumn{5}{|c|}{$\mathrm{Na}\left(\mathrm{ng} / \mathrm{m}^{3}\right)$} & \multicolumn{5}{|c|}{$\mathrm{Al}\left(\mathrm{ng} / \mathrm{m}^{3}\right)$} & \multicolumn{5}{|c|}{$\mathrm{S}\left(\mathrm{ng} / \mathrm{m}^{3}\right)$} & \multicolumn{5}{|c|}{$\mathrm{K}\left(\mathrm{ng} / \mathrm{m}^{3}\right)$} & \multicolumn{5}{|c|}{$\mathrm{Fe}\left(\mathrm{ng} / \mathrm{m}^{3}\right)$} \\
\hline Semarang & ( & 17.55 & - & 565.6 & ) & ( & 0.13 & - & 138.9 & ) & ( & 82.50 & - & 1063 & ) & 1 & 35.29 & - & 458.2 & ) & ( & 88.81 & - & 88.26 & ) \\
\hline Surabaya & ( & 159.3 & - & 477.2 & ) & ( & 140.0 & - & 282.1 & ) & ( & 355.5 & - & 849.1 & ) & ( & 127.5 & - & 640.2 & ) & ( & 352.8 & - & 74.21 & ) \\
\hline Pekanbaru & ( & 1.91 & - & 254.1 & ) & ( & 22.19 & - & 611.4 & ) & ( & 175.2 & - & 1178 & ) & ( & 4.31 & - & 596.2 & ) & ( & 109.8 & - & 107.1 & ) \\
\hline Bandung & ( & 33.98 & - & 319.5 & ) & ( & 112.0 & - & 357.0 & ) & ( & 13.53 & - & 1398 & ) & 1 & 6.71 & - & 429.8 & ) & ( & 284.3 & - & 44.45 & ) \\
\hline Jakarta & ( & 25.75 & - & 261.6 & ) & ( & 116.4 & - & 351.1 & ) & ( & 48.99 & - & 1276 & ) & 1 & 8.41 & - & 332.8 & ) & ( & 254.0 & - & 30.69 & ) \\
\hline Tangerang & ( & 5.31 & - & 350.8 & ) & ( & 121.5 & - & 230.5 & ) & ( & 5.35 & - & 973.6 & ) & 1 & 3.71 & - & 284.3 & ) & ( & 222.7 & - & 21.07 & ) \\
\hline Bali & ( & 138.3 & - & 568.3 & ) & ( & 163.8 & - & 274.3 & ) & ( & 355.9 & - & 1146 & ) & ( & 247.6 & - & 591.6 & ) & ( & 267.2 & - & 25.36 & ) \\
\hline
\end{tabular}

$\mathrm{ng} / \mathrm{m}^{3}$, disajikan pada Tabel 1 .

Kisaran konsentrasi Na, Al, S, K, Fe di beberapa kota di Indonesia disajikan pada Tabel 1. Sulfur yang tertinggi hasil pengujian di 10 lokasi pemantauan secara berurut terdapat di Kota Bandung, Jakarta, Surabaya, Bali, Tangerang dan Pekanbaru nilai reratanya diatas $400 \mathrm{ng} / \mathrm{m}^{3}$, dan kota lainnya berada dibawah $400 \mathrm{ng} / \mathrm{m}^{3}$. Belum ada baku mutu untuk membandingkan S di udara ambien.

Kisaran konsentrasi unsur $\mathrm{Mg}$, $\mathrm{Si}, \mathrm{Ca}$, dan $\mathrm{Zn}$ di udara ambien di beberapa kota di Indonesia disajikan pada Tabel 3. Untuk parameter magnesium $(\mathrm{Mg})$, silikon $(\mathrm{Si})$, kalsium $(\mathrm{Ca})$, dan seng (Zn), Zn yang tertinggi terdapat di Kota Surabaya, dengan nilai rerata 344,78 $\mathrm{ng} / \mathrm{m}^{3}$, nilai $\mathrm{Zn}$ kota lainnya berada dibawah $150 \mathrm{ng} / \mathrm{m}^{3}$.

Kisaran konsentrasi $\mathrm{Cr}, \mathrm{Mn}, \mathrm{Co}, \mathrm{Ni}$, dan $\mathrm{Cu}$, di beberapa kota di Indonesia, disajikan pada Tabel 4. Unsur yang paling tinggi di beberapa kota untuk parameter kromium $(\mathrm{Cr})$, mangan (Mn), kobal (Co), nikel (Ni), dan copper $(\mathrm{Cu}), \mathrm{Mn}$ yang tertinggi secara berturut terdapat di Kota Surabaya dan Jakarta dengan nilai rerata $14,07 \mathrm{ng} / \mathrm{m}^{3}$ dan $10,00 \mathrm{ng} / \mathrm{m}^{3}$, nilai Mn di kota lainnya berada dibawah $6 \mathrm{ng} / \mathrm{m}^{3}$. 
Tabel 3. Kisaran Konsentrasi Mg, $\mathrm{Si}, \mathrm{Ca}$, dan Zn di beberapa Kota di Indonesia

\begin{tabular}{|c|c|c|c|c|c|c|c|c|c|c|c|c|c|c|c|c|c|c|c|c|}
\hline \multirow{2}{*}{ Lokasi } & \multicolumn{5}{|c|}{$\operatorname{Mg}\left(\mathrm{ng} / \mathrm{m}^{3}\right)$} & \multicolumn{5}{|c|}{$\mathrm{Si}\left(\mathbf{n g} / \mathbf{m}^{3}\right)$} & \multicolumn{5}{|c|}{$\mathrm{Ca}\left(\mathrm{ng} / \mathrm{m}^{3}\right)$} & \multicolumn{5}{|c|}{$\mathrm{Zn}\left(\mathrm{ng} / \mathrm{m}^{3}\right)$} \\
\hline & & $\min$ & & $\max$ & & & $\min$ & & $\max$ & & & $\min$ & & $\max$ & & & $\min$ & & $\max$ & \\
\hline Yogya & ( & 14.41 & - & 166.3 & ) & ( & 17.10 & - & 176.6 & ) & ( & 15.75 & - & 86.33 & ) & ( & 4.33 & & 37.35 & ) \\
\hline Semarang & ( & 4.51 & - & 61.72 & ) & ( & 0.25 & - & 307.0 & ) & ( & 0.49 & - & 76.20 & ) & ( & 1.81 & - & 913.9 & ) \\
\hline Surabaya & ( & 10.27 & - & 278.6 & ) & ( & 76.46 & - & 362.9 & ) & ( & 45.97 & - & 168.74 & ) & ( & 114.1 & . & 861.51 & ) \\
\hline Palangkaraya & ( & 1.34 & - & 130.0 & ) & ( & 23.00 & - & 213.8 & ) & ( & 6.84 & - & 59.08 & ) & ( & 4.10 & 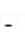 & 32.04 & ) \\
\hline Pekanbaru & ( & 7.14 & - & 74.42 & ) & ( & 23.94 & - & 744.7 & ) & ( & 2.45 & - & 205.38 & ) & ( & 2.90 & - & 29.38 & ) \\
\hline Bandung & ( & 0.79 & - & 160.2 & ) & ( & 23.20 & - & 266.1 & ) & ( & 14.37 & - & 191.17 & ) & ( & 3.97 & - & 83.83 & ) \\
\hline Jakarta & ( & 2.10 & - & 786.4 & ) & ( & 22.17 & - & 345.4 & ) & ( & 9.12 & - & 253.48 & ) & ( & 6.40 & - & 277.3 & ) \\
\hline Tangerang & ( & 4.03 & - & 159.0 & ) & ( & 17.92 & - & 239.7 & ) & ( & 4.16 & - & 103.60 & ) & ( & 3.67 & - & 433.3 & ) \\
\hline Bali & ( & 22.58 & - & 172.3 & ) & ( & 97.35 & - & 332.9 & ) & ( & 71.40 & - & 190.88 & ) & ( & 7.63 & - & 16.78 & ) \\
\hline Makassar & ( & 9.48 & - & 92.99 & ) & ( & 20.27 & - & 527.3 & ) & ( & 5.63 & - & 381.32 & ) & ( & 3.79 & - & 23.18 & ) \\
\hline
\end{tabular}

Tabel 4. Kisaran Konsentrasi Unsur Cr, Mn, Co, Ni, dan Cu di beberapa Kota di Indonesia

\begin{tabular}{|c|c|c|c|c|c|c|c|c|c|c|c|c|c|c|c|c|c|c|c|c|c|c|c|c|c|}
\hline \multirow{2}{*}{ Lokasi } & \multicolumn{5}{|c|}{$\mathrm{Cr}\left(\mathrm{ng} / \mathrm{m}^{3}\right)$} & \multicolumn{5}{|c|}{$\operatorname{Mn}\left(\mathbf{n g} / \mathbf{m}^{3}\right)$} & \multicolumn{5}{|c|}{$\operatorname{Co}\left(\mathrm{ng} / \mathrm{m}^{3}\right)$} & \multicolumn{5}{|c|}{$\mathbf{N i}\left(\mathbf{n g} / \mathbf{m}^{3}\right)$} & \multicolumn{5}{|c|}{$\mathrm{Cu}\left(\mathrm{ng} / \mathrm{m}^{3}\right)$} \\
\hline & & $\min$ & & $\max$ & & & $\min$ & & $\max$ & & & $\min$ & & $\max$ & & & $\min$ & & $\max$ & & & nin & & $\max$ & \\
\hline Yogya & ( & 3.01 & - & 0.98 & ) & ( & 3.49 & - & 2.04 & ) & ( & 1.28 & - & 3.87 & ) & ( & 1.44 & - & 0.61 & ) & ( & 1.21 & - & 1.73 & ) \\
\hline Semarang & ( & 3.32 & - & 1.04 & ) & ( & 2.95 & - & 2.74 & ) & ( & 0.24 & - & 0.27 & ) & ( & 1.07 & - & 0.33 & ) & ( & 0.80 & - & 0.83 & ) \\
\hline Surabaya & ( & 3.70 & - & 0.65 & ) & ( & 14.07 & - & 5.11 & ) & ( & 0.81 & - & 0.45 & ) & ( & 1.56 & - & 0.43 & ) & ( & 4.60 & - & 1.94 & ) \\
\hline Palangkaraya & ( & 3.06 & - & 2.25 & ) & ( & 3.24 & - & 2.47 & ) & ( & 0.39 & - & 0.23 & ) & ( & 1.65 & - & 1.69 & ) & ( & 1.01 & - & 1.10 & ) \\
\hline Pekanbaru & ( & 3.77 & - & 1.00 & ) & ( & 3.04 & - & 1.99 & ) & ( & 0.57 & - & 0.34 & ) & ( & 1.22 & - & 0.49 & ) & ( & 2.70 & - & 2.87 & ) \\
\hline Bandung & ( & 2.84 & - & 0.56 & ) & ( & 5.79 & - & 1.87 & ) & ( & 0.54 & - & 0.24 & ) & ( & 1.77 & - & 0.58 & ) & ( & 2.47 & - & 1.30 & ) \\
\hline Jakarta & ( & 3.17 & - & 0.50 & ) & ( & 10.00 & - & 5.34 & ) & ( & 0.62 & - & 0.33 & ) & ( & 1.52 & - & 0.34 & ) & ( & 6.38 & - & 4.19 & ) \\
\hline Tangerang & ( & 2.52 & - & 0.62 & ) & ( & 5.25 & - & 2.60 & ) & ( & 0.45 & - & 0.24 & ) & ( & 1.37 & - & 0.44 & ) & ( & 2.09 & - & 1.21 & ) \\
\hline Bali & ( & 2.52 & - & 0.29 & ) & ( & 4.50 & - & 1.01 & ) & ( & 0.46 & - & 0.33 & ) & ( & 1.76 & - & 0.37 & ) & ( & 1.32 & - & 0.73 & ) \\
\hline Makassar & ( & 2.05 & - & 0.20 & ) & ( & 4.43 & - & 1.44 & ) & ( & 0.58 & - & 0.34 & ) & ( & 1.59 & - & 0.44 & ) & ( & 0.88 & - & 0.33 & ) \\
\hline
\end{tabular}

\section{SIMPULAN}

Telah terdeteksi konsentrasi 15 unsur; Na, $\mathrm{Mg}, \mathrm{Al}, \mathrm{Si}, \mathrm{S}, \mathrm{K}, \mathrm{Ca}, \mathrm{Cr}, \mathrm{Mn}, \mathrm{Fe}, \mathrm{Co}, \mathrm{Ni}, \mathrm{Cu}$, $\mathrm{Zn}, \mathrm{Pb}$, pada $\mathrm{PM}_{2.5}$ dalam udara ambien di 10 lokasi yaitu Yogyakarta, Semarang, Surabaya, Palangkaraya, Pekanbaru, Bandung, Jakarta, Tangerang (Serpong), Bali, dan Makassar.

Kisaran kadar $\mathrm{Na}, \mathrm{Mg}, \mathrm{Al}, \mathrm{Si}, \mathrm{S}, \mathrm{K}, \mathrm{Ca}, \mathrm{Cr}$, $\mathrm{Mn}, \mathrm{Fe}, \mathrm{Co}, \mathrm{Ni}, \mathrm{Cu}, \mathrm{Zn}$, dan $\mathrm{Pb}$, pada $\mathrm{PM}_{2.5}$ secara berurut $\left(\mathrm{ng} / \mathrm{m}^{3}\right) ; 1,90-667 ; 1,33-786$; $0,13-1020 ; 0,2-744 ; 2,54-1397 ; 3,7-640$ ; $0,48-381 ; 1,3-7,2 ; 0,02-22,5 ; 1,94-$ $1561 ; 0,018-18,52 ; 0,26-13 ; 0,05-18,79$ ;2,9-913;0,2-2664,2 .
Dari semua unsur yang dipantau, hanya unsur $\mathrm{Pb}$ yang baru diatur keberadaannya diudara, yaitu pada Peraturan Pemerintah No. 41 tahun 1999 tentang pengendalian pencemaran udara, dengan nilai baku mutu $\mathrm{Pb}$ di dalam TSP 2 $\mu \mathrm{g} / \mathrm{m}^{3}$ atau $2000 \mathrm{ng} / \mathrm{m} 3$. Jika dibandingkan dengan baku mutu negara- negara maju (USEPA) sudah menetapkan baku mutu $\mathrm{Pb}$ di udara ambien adalah $250 \mathrm{ng} / \mathrm{m}^{3}$. $[1,8]$

Data hasil pemantauan terhadap unsur yang dipantau ini dapat dijadikan sebagai baseline data dan sebagai bahan dalam mengambil kebijakan untuk pemulihan kualitas lingkungan, terutama kualitas udara ambien. 
Data ini juga dapat digunakan sebagai data dasar dalam kajian baku mutu logam berat di udara ambien di Indonesia.

\section{UCAPAN TERIMAKASIH}

Penelitian ini terlaksana atas kerjasama PUSARPEDAL dengan PTNBR BATAN Bandung, Batan Yogyakarta, Pusat Pengelolaan Ekoregion (PPE) Sumatera, PPE Balinusra, PPE Sulawesi dan Maluku, BLH Provinsi Surabaya, BLH Provinsi Semarang, BPLHD Provinsi Jawa Barat, BPLHD Provinsi DKI Jakarta, dan BLH Kota Palangkaraya yang berpartisipasi dalam pengambilan contoh uji di daerah masing-masing. Penulis juga mengucapkan terimakasih kepada seluruh personil bidang pemantauan Pusarpedal, dan kelompok teknik analisis radiometri Batan yang terlibat dalam sampling dan analisis pada kajian logam berat ini, serta semua pihak yang telah membantu terlaksananya kegiatan ini.

\section{DAFTAR PUSTAKA}

(1) Peraturan Pemerintah Republik Indonesia No. 14/1999 tentang Pengendalian Pencemaran Udara

(2) Keputusan Kepala Bapedal No. 205/1996 tentang Pedoman Teknis Pengendalian Pencemaran Udara Sumber Tidak Bergerak.

(3) Maenhaut W, Francois F, Andcafmeyer J. The Gent stacked filter unit sampler for collection of atmospheric aerosolsin two size fractions. IAEA NAHRES-19; 1993

(4) Hopke PK, Xie Y, Raunemaa T,Bieglski S, Landsberger S, Maenhaut W, Artoxo P, Cohen DD.Characterization of Gent stacked filter unit PM10 sampler. Aerosol Science and Technology
1997; 27: 726-35.

(5) Cohen, D.D., Taha, G., Stelcer,E.D., Garton, D., Box, G., The Measurement and Sources of Fine Particle Elemental Carbon at Several Key Sites in NSW over the Past Eight Years, Journal of Geophysical 102 (2000).

(6) Chung.H.Serena and Senfeld. H. Jhon, Global Radiative Effect of Particulate Black Carbon,California Air Resources Board and the California Environemntal Protection Agency, 2005.

(7) Muhayatun, Achmad Hidayat, Diah. Ambien Air Concentration of PM2,5 and PM10 in Bandung and Lembang in 2000-2006. Indonesian Journal of Science and Nuclear Technology 2008; X(1): 53-9

(8) Muhayatun Santoso, Diah DwianaLestiani, Rita Mukhtar, Esrom Hamoangan, Halimah Syafrul, Andreas Markwitz, Philip K. Hopke, Preliminary Study of the Sources of Ambient Air Pollution in Serpong, Indonesia. Atmospheric Pollution Research (2) 2011, hal 190-196

(9) Edwar, J.D., Ogren, J.A., Weiss, R.A., and Charlson, R.J., Particle air pollutants, Atmos. Environ., 17 (1983) 2337-2341

(10) Muhayatun Santoso, Diah Dwiana Lestianim David D. Cohen, LongRange Transport Partikulat Udara Halus di Bandung Indonesia. ISSN 2085 - 2797, hal 255 